\title{
Determinant Analysis of Hedging Policy (Study on Non-Financial Company)
}

\author{
Marinus Vito Winasseto*, Wiwik Utami \\ Program Pascasarjana, Universitas Mercu Buana
}

DOI: 10.36348/SJBMS.2019.v04i10.004 ～| Received: 08.10.2019| Accepted: 15.10 .2019 | Published: 30.10 .2019

*Corresponding author: Marinus Vito

\section{Abstract}

Hedging is one of the alternatives used to minimize risk in the company, especially the risk due to exchange rate fluctuations. It is possible to conduct hedging activities to protect the company from the risk of exchange rate fluctuations. The purpose of this study was to determine the effect of growth, leverage firm size, cash flow and liquidity of the hedging decision on non-financial companies. In this study, measurement companies use hedging or not will be seen in the annual financial statements. The object used in this study were non-financial companies listed in Indonesia Stock Exchange for the period 2015-2017. The analytical method is multiple regression. The results showed that leverage has a significant effect on hedging activity. The cash flow has a negative and significant effect on hedging activity.

Keywords: hedging, sales growth, leverage, size, cash flow, liquidity.

Copyright @ 2019: This is an open-access article distributed under the terms of the Creative Commons Attribution license which permits unrestricted use, distribution, and reproduction in any medium for non-commercial use (NonCommercial, or CC-BY-NC) provided the original author and source are credited.

\section{INTRODUCTION}

Companies that conduct international trade transactions will more complicated problems when companies only with the domestic market, this is due to the use of different currencies in each country. The currency of each country is assessed from the perspective of other countries' currencies by using the concept of exchange rates or exchange rates [1]. Griffin \& Pustay [2] states that currency exchange rates can be interpreted as the amount of domestic currency that must be spent to obtain a unit of foreign currency. The imbalance of demand and supply of a currency results in a fluctuating exchange rate resulting in exchange rate uncertainty which creates exchange rate risk [2].

The results of the BPK to examination of the 2012 Central Government Financial Report indicate an increase in foreign debt from 2012 worth Rp. 1,981 Trillion to Rp. 2,755 Trillion or an increase of Rp. 393 trillion. In 2017, foreign debt reached US \$ 352.2 billion or around Rp.4,849 trillion (exchange rate Rp13,769), this number rose $10.1 \%$ from 2016. The increase in debt was one of them triggered by a foreign exchange difference of Rp. 163.24 trillion and the government must pay for the exchange rate difference without any additional benefits from the payment. BPK mentioned the need for policies in managing government foreign debt to overcome exchange rate risk, namely by conducting hedging transactions, because the government does not want to bear losses due to exchange rate fluctuations.

A company that does not escape the risk of exchange rate fluctuations is banking. The bank is a company that has the function to collect and channel funds to the community besides providing banking services. An example of its operational activities is to provide credit to customers, in the provision of credit it does not rule out the possibility that customers experience defaults with various factors that cause it. This risk is referred to as credit risk, this risk cannot be eliminated or avoided, but with company policy, this risk can be managed properly to minimize risk in the company. Banks that have foreign debt dependents are required to carry out hedging transactions in domestic banking. These rules are contained in the Bank 
Marinus Vito Winasseto \& Wiwik Utami; Saudi J Bus Manag Stud, Oct 2019; 4(10): 814-821

Indonesia Regulation (PBI) no.16/21/PBI/2014 concerning the principle of prudence in the management of corporate foreign debt on the Bank.

Companies hedging with derivative instruments can be influenced by company internal factors such as liquidity [30, 4]. The liquidity in this study was assessed by looking at the current ratio value. Companies that experience financial difficulties will begin to pay bills slowly (business debt), bank loans, and other obligations that will increase current liabilities. If current liabilities rise faster than current assets, the current ratio will decrease, and this is a sign of a problem [5]. Sang, et al., [6] and Caudhry [7] prove that liquidity has a negative effect on hedging decisions. This result is supported by Andison's research [4], his research on manufacturing companies in the 2013-2015 period listed on the Indonesia Stock Exchange, proves that liquidity has a negative and significant effect on hedging. Whereas research conducted by Putro [3]; Nguyen and Faff [8], results that liquidity has a positive effect on hedging decisions.

Other factors that influence hedging actions are growth opportunity [9], growth opportunity shows that the company is developing well with a large amount of funding needs in the company used to finance the growth of the company in the future Ahmad and Haris [10]; Putro and Chabachib, [3]; Dewi and Purnawati [11], stated that growth opportunity has a significant positive effect on hedging use policies, this shows that when growth in companies increases, it will increasingly encourage companies to hedge. Because companies with high growth opportunities will attract investors to invest and companies will need additional funds to finance the company's activities. Instead, research conducted by Ameer [12]; Widyagoca and Lestari [13] say that growth opportunity has a negative effect on hedging decision making. While the research conducted by Gunarti [14]; Nuzul and Lautania [15] which show the results that growth opportunity is not significant to hedging policies.

Leverage is an internal factor that influences the company's actions to hedge [15]. Leverage is a ratio used to measure the extent to which a company is financed with debt [16]. A company that has a high leverage ratio, the higher the risk faced by the company due to higher interest rates so that management will minimize the risk by doing hedging activities [5]. Damanik [17], in his research, proved that leverage has a positive and significant effect on banking companies in Indonesia which are listed on the Indonesia Stock Exchange for the period 2009-2013. The higher the leverage that is borne by the company, the greater the hedging action that needs to be done to reduce the adverse effects of risk, so the greater the chance for companies to make decisions on derivative instruments as hedging decision making. In contrast to the research of Widyagoca and Lestari [18], in his research through case studies of PT. Indosat Tbk, the test results prove that the leverage ratio has a negative effect on hedging decisions made by the company.

\section{LITERATURE REVIEW, FRAMEWORK AND HYPOTHESES Literature Review Agency Teory}

Jensen and Meckling [19], agency theory states that between management and owners have different interests. Companies that separate management and ownership functions will be vulnerable to conflict. The agency model designs a system that involves both parties, so a work contract is required between the owner (principal) and management (agent). The agreement is expected to maximize the principal's utility and can guarantee agents to receive rewards from the results of company management activities. The difference in importance between the owner and management lies in maximizing the benefits (utility) of the owner (principal) with the constraints (utility) benefits (utility) and incentives that will be received by management (agent). Different interests often cause conflicts of interest between shareholders/owners (principal) and management (agent). There may be a dilemma among owners with management as agents regarding the implementation of hedging. If the company's management hedges, there will be a possibility of losses from hedging transactions which will be reflected in the company's financial statements. When shareholders see a loss from hedging transactions on the financial statements, shareholders can blame management for carrying out the hedge. However, on the other hand, if management does not hedge, the owner can assess management is not anticipative of the weakening condition of the rupiah exchange rate on the foreign exchange market. The management's lack of anticipation towards the weakening tendency of the rupiah can reduce the company's profit.

\section{Sales Growth}

Companies that experience rapid growth also tend to choose debt as a source of funding compared to companies that have a slow growth rate, also expressed by Aretz et al. [20]. The company also tends to maintain its income to be reinvested and at the same time, the company is expected to continue to rely on funding through greater debt. Companies that have high growth opportunities require additional capital from external parties in strong amounts to finance the company's activities. External capital can be obtained from foreign parties so there is a risk of changes in currency exchange rates. When the local currency (rupiah) depreciates/weakens against foreign currency (U \$ dollars), it will cause the value of debt denominated in foreign currencies (U $\$$ dollars) to increase. This incident will be very detrimental to the company in meeting debt obligations and interest payments. Thus companies that have high growth opportunities tend to become hedgers to protect their 
companies $[21,12]$ so that there is a positive relationship between growth opportunity and hedging activities.

\section{Leverage}

Debt to Equity Ratio (DER) reflects the company's ability to meet its obligations as indicated by some part of its own capital or equity used to pay debts. Debt to Equity Ratio (DER) is a comparison between the total debt held by a company and its total equity. Mathematically Debt to Equity Ratio (DER) can be formulated as follows [23]. Total debt is total liabilities (both short-term and long-term debt), while total shareholder's equity is the company's own total capital. This ratio shows the composition of the capital structure of total loans (debt) to the total capital owned by the company. The higher Debt to Equity Ratio (DER) shows the composition of total debt (both short and long term) is greater than the total own capital so that the greater the company's burden on external parties (creditors) [23].

\section{Firm Size}

Firm Size affects the decision making in the company, and also affects the ease of obtaining funding sources that come from internal or external. The greater the company will tend to use hedging activities to protect the assets of the company because the greater the risk faced by the company will also be even greater. So that large companies will do better risk management in their companies compared to small companies [23].

\section{Cash Flow}

Cash flow can provide clues about the uncertainty of business revenue to be obtained by the company is very high. Companies that have very high business revenues will potentially face financial risks, such as bankruptcy costs. Cash flow within a company is affected by changes in exchange rates that occur in the company's operational activities such as exports and imports. Companies that have high cash flow will have a big incentive to take advantage of hedging activities to minimize existing risks, such as bankruptcy costs. The higher the cash flow affects the company in conducting hedging activities; this is because if a company has a higher cash flow, the probability of implementing a company's hedging policy will increase [24].

\section{Liquidity}

Liquidity ratio is a ratio to measure the ability to meet short-term obligations when billed by a company [25]. In other words, it can repay the disbursement of the deposit when it is billed and can meet the credit request that has been submitted. The importance of liquidity can be seen by considering the impact that comes from the company's inability to meet its short-term obligations. Lack of liquidity will prevent companies from getting discounts, leading to investment sales, which can lead to bankruptcy [16]. Liquidity shows the ability of a company to fulfill its financial obligations that must be fulfilled immediately, or the company's ability to meet financial obligations when billed.

\section{Hedging}

Hedging is a contractual action that aims to protect the company from the risk of market value [26]. Hedging or hedging is a very popular term in futures trading. Hedging is one of the economic functions of futures trading, i.e. transfer of risk, besides that it is a strategy to reduce the risk of loss caused by fluctuating prices and changes in exchange rates in the future. Merrick [27] and Kusmanto [28], hedging or hedge is defined as follows: "A hedge is one or more performed traders to protect an existing market exposure against market movement". So basically hedging is a way for producers or investors to protect the position of an asset or (underlying assets) from the risk of market changes.

\section{Framework}

\section{Effect of Growth on Hedging Policies}

Growth is a measure of a company's opportunities in developing its business in the future [29]. High-growth companies prefer debt for corporate development funding sources compared to companies with low growth [30]. Growth Opportunities can show the opportunities for a company. The higher growth show the opportunity for a company to advance is also high, so the company is seeing the opportunity to grow requires large amounts of funds to finance the development and growth of the company. The results of research by Nance, Smith, and Smithson [31], Hardanto [3] and Karol Marek Klimczak [32] showed the same results, namely that growth opportunities had a positive and significant effect on the use of derivative instruments.

\section{Effect of Leverage on Hedging Policies}

Leverage is usually used to describe the company's ability to use assets or funds that have a fixed burden to increase the level of corporate income [33]. Whereas Ismanu [26] defines leverage as the potential use of financial costs to grow the effect of increasing changes in earnings before interest and taxes. The higher the leverage charged by a company, the higher the hedging measures taken to reduce the impact of bad risk, because the debt used is greater than the quantity of capital a company will pose a bankruptcy risk, with greater risk the company needs to cope with hedging. In the research of Nguyen and Faff [8], Guniarti, Fay [14], and Paranita [34] get the appropriate results, namely leverage influences the use of foreign exchange derivative instruments.

\section{Effect of Firm Size on Hedging Policies}

The size of a larger company with more operational activities and more risky than a smaller company. Companies that are most likely to carry out transactions that will reach several countries, and when it has crossed various countries, the company will face 
transactions with a variety of different currencies. Then there will be transaction exposures in the company and face the risk of exchange rate fluctuations, so that companies that have a large size will be more inclined to carry out risk management by hedging to protect their companies [30,3 in Friska Saragih [9].

\section{Effect of Cash Flow on Hedging Policies}

Cash Flow can indicate that the uncertainty of business income is very high; the uncertainty has the potential to get financial risks, such as bankruptcy. Companies that have high cash flow will have a big incentive to take advantage of hedging activities to minimize existing risks, such as bankruptcy costs. The higher the cash flow affects the company in conducting hedging activities; this is because if a company has a higher cash flow, the probability of implementing a company's hedging policy will increase [24].

\section{Effect of Liquidity on Hedging Policies}

Liquidity shows the ability of a company to fulfill its financial obligations that must be fulfilled immediately, or the company's ability to meet financial obligations when billed. So it can be concluded that liquidity is the company's ability to meet short-term financial obligations that must be fulfilled immediately. Ameer [12] Liquidity has a positive and significant effect on hedging activities. The higher liquidity of companies proxied by current assets on current liability proves that the company reduces hedging activities.

\section{Hypothesis}

From the formulation of the problem posed in this study, statistical hypothesis remains to be verified as follows:
H1: Sales growth effects on Hedging Policies

H2: Leverage effects on Hedging Policies

H3: Firm Size effects on Hedging Policies

H4: Cash Flow effects on Hedging Policies

H4: Liquidity effects on Hedging Policies

\section{Metodology and hypotesis development}

\section{Research design}

This type of research used in this research is descriptive quantitative research. Quantitative research methods are one type of research whose specifications are systematic, planned and structured. Sugiyono [35], quantitative research methods data interpreted as a research method based on the philosophy of positivism, used to examine a particular population or sample. Sampling techniques are generally carried out randomly, data collection using research instruments, quantitative/statistical data analysis to test the hypotheses that have been set.

\section{Operationalization Variable Definition and Measurement of Variables Dependent Variable (Y)}

The dependent variable in this study is hedging used in Donohoe's [36] research to measure the use of derivatives in Donohoe's [36] research when examining the relationship between the use of financial derivatives and tax avoidance activities. Just like Donohoe [36], this study measures the use of financial derivatives by using the absolute value of the net fair value of derivative instruments. The following ratios are used to measure the variable use of financial derivatives [3].

\section{FVDER $=\frac{\text { Absolut value form fair value of Derivatif } 1 \text { nstrument }}{\text { Total Asset } y \text { ear } t-1}$}

\section{Independent Variable $(\mathrm{X})$ \\ Sales Growth}

High growth indicates the opportunity for companies to progress even greater. Sales growth is the change in company sales can be measured based on the ratio between total sales of the current period (sales $t$ ) minus the previous period (sales t-1) to total sales of the previous period (sales t1). Growth calculation according to Sofyan [37] s can be formulated as follows:

$$
\text { Growth }=(\text { Sales } \mathrm{t}-\text { Sales } \mathrm{t}-1) /(\text { Sales } \mathrm{t}-1)
$$

\section{Leverage}

Leverage is measured by Debt to Equity Ratio (DER) reflecting the company's ability to meet its obligations as indicated by some part of its own capital or equity used to pay debts. Debt to Equity Ratio (DER) is a comparison between the total debt held by a company and its total equity. Mathematically Debt to Equity Ratio (DER) can be formulated as follows [38]:

$$
\text { DER }=(\text { Total Liabilities }) /(\text { Total Equity })
$$

\section{Firm Size}

Firm Size affects the decision making in the company, and also affects the ease of obtaining funding sources that come from internal or external. The greater the company will tend to use hedging activities to protect the assets of the company because the greater the risk faced by the company will also be even greater. So that large companies will do better risk management in their companies compared to small companies [3]. Proxies used in measuring the size of this company are: 
Firm Size $=$ In Total Asset

\section{Cash Flow}

Cash flow is operating cash inflows with expenses needed to maintain operating cash flows in the future. Cash flow can indicate that the uncertainty of business income, the uncertainty has the potential to face financial risks, such as bankruptcy costs [39]. Cash flow is the operating cash flow divided by total assets. The formula for calculating cash flow is [32]:

$$
\text { Cash Flow }=\frac{C F 0}{\text { Total Aset }}
$$

\section{Liquidity}

Liquidity shows the ability of a company to fulfill its financial obligations that must be fulfilled immediately, or the company's ability to meet financial obligations when billed. So it can be concluded that liquidity is the company's ability to meet short-term financial obligations that must be fulfilled immediately. In this study, the liquidity ratio used to measure a company's ability to pay debt is the current ratio. The current ratio is the ratio of current assets compared to total current debt owned by the company. Current ratio can be formulated as follows [13].

$$
\text { Current Rasio }=\frac{\text { Current Asset }}{\text { Current Liabilities }}
$$

\section{RESULT AND DISCUSSION}

\section{Table-1: Samples}

\begin{tabular}{|l|l|}
\hline \multicolumn{1}{|c|}{ Information } & Number \\
\hline $\begin{array}{l}\text { Non-financial company that disclose the } \\
2015-2017\end{array}$ & 433 \\
\hline $\begin{array}{l}\text { Companies that did not have complete data } \\
\text { for the 2015-2017 period }\end{array}$ & -59 \\
\hline $\begin{array}{l}\text { Companies that do not conduct hedging } \\
\text { activities for the period 2015-2017 }\end{array}$ & -362 \\
\hline Number of Research Samples & $\mathbf{3 6}$ \\
\hline
\end{tabular}

This study uses a population of banking companies listed on the Indonesia Stock Exchange during the 2014-2017 period. The research sample was obtained by using purposive sampling method with the following criteria: (1) Banking Companies that publish financial statements for 2015-2017 and can be accessed through the company's website and the Indonesia Stock Exchange website; (2) The company publishes financial statements for three consecutive years (2015-2017) and provides complete information regarding the variables under study; (3) non finacial companies that engage in hedging activities during the observation period 20142017; (4) Banking companies that issue financial statements in rupiah currency during 2015-2017. Based on the sample selection criteria with purposive sampling obtained the following research sample.

Based on table 1, the number of banking companies listed on the Indonesia Stock Exchange in the 2015-2017 period amounted to 433 companies. Companies that do not have complete data for 59 companies. Non-financial companies that are predicted not to do hedging activities are 362 companies. So that the research sample is 12 non-financial companies with 3 years of observation so that the total sample during the 2015-2017 period is 36 observations of the company's annual financial statements.

Analyzing data used statistical inferences (inductive statistics). The level of significance of the correlation between the independent variable $(\mathrm{x})$ and the independent variable (y), it is a necessary statistical model to test the hypothesis set. Therefore, the research hypothesis formulated indicates the correlative study; the technique used to analyze the level of significance for the independent variable on the dependent is a multiple linear regression model (multiple regression analysis).

$$
\mathrm{HEDG}=\alpha+\beta_{1} \mathrm{LEV}+\beta_{2} \text { GROWTH }+\beta_{3} \mathrm{Size}+\beta_{4} \mathrm{CFO}+\beta_{5} \mathrm{LIQ}+\mathrm{e}
$$

HEDG = hedging is measured by net fair value of derivative instruments;

LIQ = liquidity is measured by LDR or loan to deposit ratio;

SALES GROWTH= growth is measured based on the ratio between total sales of the current period minus the previous period to total sales of the previous period

LEV = leverage is measured by the ratio of total debt divided by total assets.

SIZE = in total Aset,

$\mathrm{CFO}=$ cash flow from operation ratio

Descriptive statistics for the number of test samples are 36 companies period of 2015-2017. This test includes testing the minimum value, the value of maximum, average and standard deviation. Descriptive statistical result.

Table-2: Descriptive Statictics

\begin{tabular}{|l|l|l|}
\hline & \multirow{2}{*}{ Mean } & Std. \\
\cline { 3 - 3 } & & Deviation \\
\hline HEDG & 0,02 & 0,03 \\
\hline LEV & 0,59 & 0,17 \\
\hline GROW & 0,03 & 0,11 \\
\hline SIZE & 13,35 & 0,54 \\
\hline FLOW & 0,1 & 0,06 \\
\hline LIQ & 1,13 & 0,52 \\
\hline
\end{tabular}

Based on the results of testing descriptive statistics in table 2 on the number of samples of 36 nonfinancial companies in the 2015-2017 periods, an 
illustration is obtained for the average value of hedging activities of 0.02 with a minimum value of 0.00 and a maximum value of 0.13 with a standard deviation of 0.03 . Which means that the distribution of data is not very varied, so that the data is good enough to be studied.

\begin{tabular}{|l|r|r|r|}
\multicolumn{1}{|c}{ Table-3: Result } \\
\begin{tabular}{|lrrr|}
\hline & \multicolumn{1}{c|}{ B } & \multicolumn{1}{c|}{ t } & \multicolumn{1}{c|}{ Sig. } \\
\hline (Constant) & $-1,599$ & $-1,058$ & 0,299 \\
\hline Leverage & 0,009 & 3,176 & 0,003 \\
\hline Growth & $-0,222$ & $-0,495$ & 0,624 \\
\hline Size & 0,11 & 1,047 & 0,303 \\
\hline Flow & $-1,713$ & $-2,275$ & 0,03 \\
\hline Likuiditas & 0,003 & 0,023 & 0,982 \\
\hline
\end{tabular}
\end{tabular}

Based on the hypothesis testing in table 3,the first hypothesis (1), the effect of leverage ratio on hedging activity. From the test results in table 4.7 obtained the regression coefficient $(\beta) 0.009$, this value proves that every $1 \%$ increase in the leverage ratio variable will increase hedging activity by $0.009 \%$ with a significance value of $0.013<0.05$, it can be concluded that the leverage ratio variable has a positive and significant effect against hedging activities. Companies that have a high leverage ratio, the higher the risk faced by the company due to higher interest rates so that management will minimize these risks by doing hedging activities [5]. Aretz et al. [20] states that there is a tendency for companies that uses more debt in their capital structure to hedge. A company with a higher leverage ratio indicates that the company is facing the risk of financial distress. In other words, companies will tend to fail on loans when borrowing more from creditors. Therefore, hedging can provide a very important contribution in helping companies to handle a competitive financial environment [40].

This study supports the research of Afza and Atia [41] and Damanik [17], in his research proving that leverage has a positive and significant effect on banking companies in Indonesia that are listed on the Indonesia Stock Exchange 2009-2013. The higher the leverage that is borne by the company, the greater the hedging action that needs to be done to reduce the adverse effects of risk, so the greater the chance for companies to make decisions on derivative instruments as hedging decision making.

In the second hypothesis (2), namely testing the effect of sales growth on hedging activity. From the test results obtained coefficient value $(\beta)-, 222$, this result proves that every $1 \%$ increase in growth opportunity variable will decrease hedging activity by $0,222 \%$ with a significant value of $0.624>0.05$, this value proves to support the second hypothesis (2), it can be concluded that growth opportunity no significant effect on hedging activities. Companies with high growth rates need more funds in the future, especially external funds to meet their investment needs or to meet the needs to finance their growth [42]. The higher growth opportunity shows the opportunity for a company to advance too high so that the company in seeing the opportunity to grow requires a large amount of funds in financing the development and growth of the company.

The Third hypothesis (3), examines the effect of firm size on hedging activities. From the test results obtained regression coefficient $(\beta) 0.110$, this value proves that every $1 \%$ increase in the firm size ratio variable will increase hedging activity by $0.110 \%$ with a significance value of $0.303>0.05$, this result fails to accept hypothesis one (1), it can be concluded that there is no effect of firm Size on hedging activities. The size of a larger company with more operational activities and more risky than a smaller company. Companies that are most likely to carry out transactions that will reach several countries, and when it has crossed various countries, the company will face transactions with a variety of different currencies. Then there will be transaction exposures in the company and face the risk of exchange rate fluctuations, so companies that have a large size will be more likely to do risk management without hedging to protect their companies.

The Fourth (4), which is testing the effect of cash flow on hedging activities. From the test results in table 3 obtained regression coefficient $(\beta)-1.713$, this value proves that every $1 \%$ increase in the variable leverage ratio will increase hedging activity by $-1.713 \%$ with a significance value of $0.03<0.05$, it can be concluded that the cash flow ratio variable has a negatif effect and significant to hedging activities.

The fifth hypothesis (5) examines the effect of liqudity on hedging activity the coefficient $(\beta) 0,003$ is obtained, this value proves that every $1 \%$ increase in the liquidity variable will reduce hedging activity by $0.003 \%$. While the significance value is $0.982>0.05$, this result fails to accept the first hypothesis (1), it can be concluded that there is no effect of liquidity on hedging activities. The more liquid a company is, the company can fulfill its short-term obligations with the current funds owned. The inability of the company to pay off its short-term obligations can be caused by several factors, such as the company does not have funds at all, or in fact the company is not experiencing financial difficulties, but when its short-term liabilities are due, the company still has to disburse a number of its current assets into cash such as collection receivables. If the company can pay off its short-term obligations, the company is said to be a liquid company.

\section{CONCLUTION}

Based on the testing of the first hypothesis (1), the leverage ratio has a positive and significant effect on hedging activity. Companies that have a high leverage ratio, the higher the risk faced by the company due to 
higher interest rates so that management will minimize these risks by doing hedging

Besides that, sales growth has no significant influence on hedging activity. The higher sales growth shows the opportunity for a company to advance too high, so that the company in seeing the opportunity to grow requires a large amount of funds in financing the development and growth of the company Because companies with high growth opportunities will attract investors to invest and companies will need additional funds to finance the company's activities.

In hypothesis third (3), which tests the effect of firm size on hedging activity and it can be concluded that there is no effect of firm size on hedging activity. The size of a larger company with more operational activities and more risky than a smaller company. Companies that are most likely to carry out transactions that will reach several countries, and when it has crossed various countries, the company will face transactions with a variety of different currencies. Then there will be transaction exposures in the company and face the risk of exchange rate fluctuations, so companies that have a large size will be more likely to do risk management without hedging to protect their companies

In hypothesis four (4), namely cash flow which has a negative and significant effect on the use of derivative instruments as hedging decision making "is proven. The results of this study have confirmed research conducted by Ahmad [10], Paranita [34] and Nguyen and Faff [8] that cash flow has a negative effect on hedging. The results of this study indicate that the higher the company's cash flow will further reduce the possibility of the company to hedge because of the company's adequate cash flow conditions.

Liquidity does not affect hedging activity. The more liquid a company can be said that the company can fulfill its short-term obligations with the current funds owned. The more liquid a company is, the more the company avoids the risk of financial distress and the lower the possibility of companies using hedging. Because liquid companies have sufficient reserves of funds to deal with risks that might occur so they do not require hedging.

In the next study can add other variables that can affect hedging activities such as profitability and financial distress variables, hedging activity and expanding sample financial company research because financial companies such as manufacturing conduct foreign trade that uses the exchange rate as a transaction and adds years of research, this is so that the research sample is more representative in explaining the research population.

\section{REFFERENCES}

1. Fahmi, I. (2012). Analisis Laporan Keuangan. Catatan Kedua. Alfabeta. Bandung.

2. Griffin, R. W., \& Pustay, M. (2010). Strategies for analyzing and entering foreign markets. International Business (6th ed.). Upper Saddle River, NJ: Prentice Hall.

3. Putro, S., Hardanto. (2012). Analisis Faktor yang Mempengaruhi Penggunaan Instrumen Derivatif Sebagai Pengambilan Keputusan Hedging (Studi kasus pada Perusahaan Automotive and Allied Products yang Terdaftar di BEI Periode 20062011). Skripsi pada Fakultas Ekonomi dan Bisnis Universitas Diponegoro: Yogyakarta.

4. Andison., Resti Yulistia M dan Arie Frinola Minovia. (2017). Financial Distress Pemoderasi Likuiditas terhadap Hedging. Studi Empiris pada Perusahaan Manufaktur di Indonesia. SNA 20 Jember

5. Brigham, E. F., \& Houston, J. F. (2010). Dasardasar Manajemen Keuangan, Edisi 11 Buku 1. Jakarta: Salemba Empat.

6. Sang, L. T., Karamah, Z., \& Osman, Z. (2013). The Determinants Of Corporate Hedging. Journal of Asian Academy of Applied Business, 2, 44-45.

7. Chaudhry, D., Mehmood, M. S., \& Mehmood, A. (2014). Determinants of corporate hedging policies and derivatives usage in risk management practices of non-financial firms. Wulfenia Journal, ISI Indexed, Impact Factor 0.267, 21(7), 293-310.

8. Faff, R. W., Gharghori, P., Ip, B., \& Nguyen, A. (2012). Return-based style analysis in Australian funds. Multinational Finance Journal, 16(3/4), 155-188.

9. Saragih, F. (2017). Pengaruh growth opportunity, firm size, dan liquidity terhadap keputusan hedging pada perusahaan perban kan indonesia. Jurnal Ilmu Manajemen (JIM), 5(2).

10. Ahmad, N., \& Haris, B. (2012). Factors for using derivatives: evidence from Malaysian non-financial companies. Research Journal of Finance and Accounting, 3(9), 79-87.

11. Dewi, K. R. U., \& Purnawati, K. (2016). Pengaruh Market to Book Value dan Likuiditas Terhadap Keputusan Hedging Pada Perusahaan Manufaktur di BEI. E-Jurnal Manajemen, 5(1).

12. Ameer, R. (2010). Determinants of corporate hedging practices in Malaysia. International Business Research, 3(2), 120-130.

13. Jiwandhana, R. S. P., \& Triaryati, N. (2016). Pengaruh Leverege Dan Profitabilitas Terhadap Keputusan Hedging Perusahaan Manufaktur Indonesia. E-Jurnal Manajemen, 5(1).

14. Gunarti, W., \& Muis, A. (2014). Metode Pengembangan Perilaku dan Kemampuan Dasar AUD.

15. Nuzul, H., \& Lautania, M. F. (2015). Pengaruh Leverage, Financial Distress Dan Growth Options Terhadap Aktivitas Hedging Pada Perusahaan NonKeuangan Yang Terdaftar Di Bursa Efek 
Indonesia. Jurnal Dinamika Akuntansi dan Bisnis, 2(2), 104-113.

16. Mittal, K. L. (Ed.). (2013). Polyimides: synthesis, characterization, and applications (Vol. 1). Springer Science \& Business Media.

17. Damanik, D., Embree, M., \& Gorodetski, A. (2015). Spectral properties of Schrödinger operators arising in the study of quasicrystals. In Mathematics of aperiodic order (pp. 307-370). Birkhäuser, Basel.

18. Widyagoca, I. A., \& Lestari, P. V. (2016). Pengaruh Leverage, Growth Opportunities, Dan Liquidity Terhadap Pengambilan Keputusan Hedging Pt. Indosat Tbk. E-Jurnal Manajemen, 5(2).

19. Jensen, M. C., \& Meckling, W. H. (1976). Theory of the firm: Managerial behavior, agency costs and ownership structure. Journal of financial economics, 3(4), 305-360.

20. Aretz, H. (2008). A simple isotropic-distortional hardening model and its application in elasticplastic analysis of localized necking in orthotropic sheet metals. International Journal of Plasticity, 24(9), 1457-1480.

21. Nance, J. M. (1993). Gulf of Mexico shrimp fishery recruitment overfishing definition, workshop 2.

22. Ang, B. W., \& Choi, K. H. (1997). Decomposition of aggregate energy and gas emission intensities for industry: a refined Divisia index method. The Energy Journal, 59-73.

23. Ang, B. W., \& Choi, K. H. (1997). Decomposition of aggregate energy and gas emission intensities for industry: a refined Divisia index method. The Energy Journal, 59-73.

24. Goklas, F., \& Wahyudi, S. (2016). Kebijakan hedging dan faktor-faktor yang mempengaruhinya (Studi Empiris Pada Perusahaan Non Finansial yang Terdaftar Di BEI Periode 20122014) (Doctoral dissertation, Fakultas Ekonomika dan Bisnis).

25. Kasidi. (2010). Manajemen Risiko. Bogor: Ghalia Indonesia.

26. Ismail, M. B. A. (2018). Manajeman Perbankan: Dari Teori Menuju Aplikasi. Kencana.

27. Choi, S. K., Lee, J. H., Zoll, W. L., Merrick, W. C., \& Dever, T. E. (1998). Promotion of mettRNAiMet binding to ribosomes by yIF2, a bacterial IF2 homolog in yeast. Science, 280(5370), $1757-1760$

28. Kusmanto, T. Y. (2013). Mereka yang Tercerabut dari Masa Depannya: Analisis Sosiologis Problem Sosial Anak di Indonesia. Sawwa: Jurnal Studi Gender, 8(2), 225-244.

29. Myers, S. C. (1977). Determinants of corporate borrowing. Journal of financial economics, 5(2), 147-175.

30. Allayannis, G., \& Weston, J. P. (2001). The use of foreign currency derivatives and firm market value. The review of financial studies, 14(1), 243 276.

31. Ismiyanti, F., \& Sasmita, H. I. (2011). Efektivitas Hedging Kontrak Futures Komoditi Emas Dengan OLEIN. Jurnal Manajemen Teori dan Terapan| Journal of Theory and Applied Management, 4(2).

32. Klimczak, K. M. (2008). Ryzyko w teorii ekonomii. Master of Business Administration, 6 , 64-69.

33. Syamsuddin, A. (2002). Psikologi Kependidikan Perangkat Sistem Pengajaran Modul. PT. Remaja Rosdakarya. Bandung.

34. Paranita, A. (2012). Implementasi Model Pembelajaran Terpadu Tipe Integrated Pada Pembelajaran Seni Budaya di SD. Versi Elektronik). Diunduh pada tanggal, 18.

35. Sugiyono, P. D. (2012). Metode Penelitian Kuantitatif, Kulaitatif, Dan R\&D. Bandung: ALFABETA

36. Donohoe, D. R., Collins, L. B., Wali, A., Bigler, R., Sun, W., \& Bultman, S. J. (2012). The Warburg effect dictates the mechanism of butyrate-mediated histone acetylation and cell proliferation. Molecular cell, 48(4), 612-626.

37. Sofyan, A., \& Asis, A. (2013). Hukum Acara Pidana Suatu Pengantar. Yogyakarta, Rangkang Education.

38. De Silva, L. C., Miyasato, T., \& Nakatsu, R. (1997, September). Facial emotion recognition using multi-modal information. In Proceedings of ICICS, 1997 International Conference on Information, Communications and Signal Processing. Theme: Trends in Information Systems Engineering and Wireless Multimedia Communications (Cat. (). IEEE. (1), 397-401

39. Dwy Syaputry, W., Elizabeth, S. M., \& Keristin, U. Analisis pengaruh cash flow volatility, leverage, firm size, dan likuiditas terhadap aktivitas hedging pada perusahaan property and real estate yang terdaftar di bursa efek indonesia periode, 20152017.

40. Shaari, M. S., Rahim, H. A., \& Rashid, I. M. A. (2013). Relationship among population, energy consumption and economic growth in Malaysia. Int J Soc Sci, 13(1).

41. Afza, T., dan A. Alam. (2011). Determinants of Corporate Hedging Policies: A Case of Foreign Exchange and Interest Rate Derivative Usage. African Journal of Business Management, 5(14), 5792-5797.

42. Setiadi, M. I., McGuire, J. A., Brown, R. M., Zubairi, M., Iskandar, D. T., Andayani, N., ... \& Evans, B. J. (2011). Adaptive radiation and ecological opportunity in Sulawesi and Philippine fanged frog (Limnonectes) communities. The American Naturalist, 178(2), 221-240. 